\title{
Why the Apathy in American High Schools?
}

\author{
JOHN H. BISHOP
}

"A 11 too often docile, compliant, and without initiative, $^{\prime \prime}$ is how Theodore Sizer (1984, p. 54) characterized American high school students at the end of his massive study. John Goodlad (1983) described: "a general picture of considerable passivity among students" (p. 113). The high school teachers surveyed by Goodlad ranked "lack of student interest" and "lack of parental interest" as the two most important problems in education.

Studies of time use and time-on-task show that students actively engage in a learning activity for only about half the time they are in high school. A study of schools in Chicago found that public schools with high-achieving students averaged about $75 \%$ of class time for actual instruction; for schools with low achieving students, the average was $51 \%$ of class time (Frederick, 1977). Other studies have found that for reading and math instruction the average engagement rate is about 75 (Fischer et al., 1978; Goodlad, 1983; Klein, Tyle, \& Wright, 1979). Overall, Frederick, Walberg, and Rasher (1979) estimated $46.5 \%$ of the potential learning time was lost due to absence, lateness, and inattention.

In the High School and Beyond Survey, students reported spending an average of 3.5 hours per week on homework. When homework is added to engaged time at school, the total time devoted to study, instruction, and practice is only 18-22 hours per week-between 15 and $20 \%$ of the student's waking hours during the school year. By way of comparison, the typical senior spent 10 hours per week in a part-time job and about 24 hours per week watching television (A. C. Neilsen, 1987). Thus, TV occupies as much time as learning. Students in other nations spend much less time watching TV: $60 \%$ less in Switzerland and $44 \%$ less in Canada (Organization of Economic
Cooperation and Development, Table 18.1, 1986).

The student's lack of interest makes it difficult for teachers to be demanding. Sizer's description of Ms. Shiffe's class, is strikingly similar to one of the classes I visited in my research:

Even while the names of living things poured out of Shiffe's lecture, no one was taking notes. She wanted the students to know these names. They did not want to know them and were not going to learn them. Apparently no outside threat-flunking, for example-affected the students. Shiffe did her thing, the students chattered on, even in the presence of a visitor. ... Their common front of uninterest probably made examinations moot. Shiffe could not flunk them all, and, if their performance was uniformly shoddy, she would have to pass them all. Her desperation was as obvious as the students cruelty toward her. ( $p p$. 157-158)

How does a teacher avoid this treatment? Sizer's description of $\mathrm{Mr}$. Brody's class provides one example.

He signaled to the students what the minima, the few questions for a test, were; all tenth-and eleventhgraders could master these with absurdly little difficulty. The youngsters picked up the signal and kept their part of the bargain by being friendly and orderly. They did not push Brody, and he did not push them. The classroom was tranquil and bland. By my watch, over a third of the time was spent on matters other than history, and two-thirds of the classes ostensibly devoted to the subject were undemanding. Brody and his class had agreement, all right, agreement that reduced the efforts of both students and teacher to an irreducible and pathetic minimum. ( $p$. 156)

Some teachers are able to overcome the obstacles and induce their students to undertake tough learning tasks. But, for most, the student's lassitude is demoralizing. Everyone in the system recognizes the problem, but each group fixes blame on someone else. As one of my students put it:

As it stands now, there is an unending, ever increasing cyclic problem. Teacher and administrator disinterest, apathy, and their lack of dedication results in students becoming even more unmotivated and docile, which in turn allows teachers to be less interested and dedicated. If students don't care, why should teachers? If teachers don't care, why should the students? (Krista, 1987)

Yes, it is a classic chicken versus egg problem. We assign teachers the responsibility for setting high standards but we do not give them any of the tools that might be effective for inducing student observance of the academic goals of the classroom. They finally must rely on the force of their own personalities. All too often teachers compromise academic demands because the majority of the class sees no need to accept them as reasonable and legitimate.

Student apathy and lack of motivation are not the whole of the problem. Parental apathy and lack of motivation are similarly widespread. A comparative study of primary education in Taiwan, Japan, and the United States has shown that even though American children were learning the least in school, American parents were the most satisfied with the performance of their local schools (Stevenson, Lee, \& Stigler, 1986). Why are American parents holding their chil-

JoHN H. Bishop is at the Center for Advanced Human Resource Studies, New York State School of Industrial and Labor Relations, Cornell University, Ithaca, New York 14851-0925. 
dren and schools to a lower standard than Japanese and Taiwanese-as well as European-parents?

The fundamental cause of the problem is our uncritical acceptance of institutional arrangements that do not adequately recognize and reinforce student effort and achievement. During the 1960s and 1970s we adopted practices and curricula that hid a failure to teach, that protected adolescents from the consequences of failing to learn, and that prevented many of those who did learn from reaping the fruits of their labor. Although there are benefits to staying in school, most students realize few benefits from working hard while in school. The lack of incentives for effort is a consequence of three phenomena:

- The labor market fails to reward effort and achievement in high school.

- The peer group actively discourages academic effort.

- Admission to selective colleges is not based on an absolute or external standard of achievement in high school subjects. It is based instead on aptitude tests which do not assess the high school curriculum and on such measures of student performance as class rank and grade point averages, which are defined relative to classmates' performances, not relative to an external standard.

\section{The Absence of Major Economic Rewards for Effort in High School}

Students who plan to look for a job immediately after high school typically spend less time on their studies than those who plan to attend college. In large part, most see very little connection between how much they learn and their future success in the labor market. Less than a quarter of 10 th graders believe that geometry, trigonometry, biology, chemistry, and physics are needed to qualify for their first choice occupation (Longitudinal Survey of American Youth, 1988). Statistical studies of the youth labor market confirm their skepticism about the benefits of taking tough courses and studying hard:

- Employers rank "reading, writing, math, and reasoning ability" number 5 on a list of 6 abilities they look for when hiring (Survey of the $\mathrm{Na}$ tional Federation of Independent Business [NFIB] membership) ${ }^{1}$
- For students seeking part-time employment while attending high school, grades and performance on academic achievement/aptitude tests have essentially no impact on labor market success. They have (a) no effect on the chances of finding work when one is seeking it during high school, and (b) no effect on the wage rate of the jobs obtained while in high school (Hotchkiss, Bishop, \& Gardner, 1982).

- As Table 1 shows, for those who do not go to college full-time, high school grades and test scores had (a) no effect on the wage rate of the jobs obtained immediately after high school in Kang and Bishop's (1984) analysis of High School and Beyond seniors and only a 1 to $4.7 \%$ increase in wages per standard deviation improvement in test scores and grade point average in Meyer's (1982) analysis of Class of 1972 data; (b) a moderate effect on wage rates and earnings after 4 or 5 years (Gardner, 1982, found an effect of $4.8 \%$ per standard deviation of achievement and Meyer, 1982 , found an effect of 4.3 to $6.0 \%$ per standard deviation of achievement); and (c) a small negative effect on the risk of unemployment immediately after high school.
The long delay before labor market rewards are received is important because most teenagers are short-sighted, so benefits possible 10 years in the future may have little influence on their decisions.

Although the economic benefits of higher achievement to the employee are quite modest and do not appear until long after graduation, the benefits to the employer (and therefore, to national production) are immediately realized in higher productivity. Over the last 80 years, industrial psychologists have conducted hundreds of studies, involving hundreds of thousands of workers, on the relationship between productivity in particular jobs and various predictors of that productivity. They have found that scores on tests measuring competence in reading, mathematics, science, and problem solving are strongly related to productivity on the job (Ghiselli, 1973). ${ }^{2}$

Figure 1 compares the percentage effect of mathematical and verbal achievement (specifically a difference of three grade-level equivalents in test scores or .7 GPA points, on a 4 point scale) on the productivity of a clerical worker, on wages of male clerical workers (Taubman \& Wales, 1975), and on the wages of young women who have not gone to college (Kang \& Bishop, 1984; Meyer,

\section{TABLE 1 \\ Effect of Academic Achievement on the Wage Rates of High School Graduates}

\begin{tabular}{|c|c|c|c|c|c|}
\hline \multirow[b]{2}{*}{ Study and Data Set } & \multirow{2}{*}{$\begin{array}{c}\text { Date } \\
\text { of } \\
\text { Graduation }\end{array}$} & \multirow[b]{2}{*}{ Age } & \multirow{2}{*}{$\begin{array}{c}\text { Achievement } \\
\text { Measures }\end{array}$} & \multicolumn{2}{|c|}{$\begin{array}{c}\text { Percent Change } \\
\text { in Wage Rate }\end{array}$} \\
\hline & & & & Male & Female \\
\hline \multicolumn{6}{|l|}{ Wage Rates } \\
\hline $\begin{array}{l}\text { Kang \& Bishop (1985) } \\
\text { High School \& Beyond }\end{array}$ & 1980 & 19 & $\begin{array}{l}\text { Test-Math, Voc, Read } \\
\text { GPA in Grade } 12\end{array}$ & $\begin{array}{r}-1.9 \\
.6\end{array}$ & $\begin{array}{l}-.5 \\
2.2\end{array}$ \\
\hline $\begin{array}{l}\text { Gardner (1983) } \\
\text { NLS Youth }\end{array}$ & $1976-1982$ & $19-24$ & AFQT & 4.8 & 4.8 \\
\hline $\begin{array}{l}\text { Daymont \& Rumberger } \\
\text { NLS Youth (1982) }\end{array}$ & $1976-1979$ & $19-21$ & GPA in Grade 9 & .3 & 2.7 \\
\hline $\begin{array}{l}\text { Meyer (1982) } \\
\text { (Weekly earnings) } \\
\text { Class of } 1972\end{array}$ & 1972 & 19 & $\begin{array}{l}\text { Class Rank Grade } 12 \\
\text { Test Composite }\end{array}$ & $\begin{array}{l}0.0 \\
1.2\end{array}$ & $\begin{array}{l}2.5 \\
2.2\end{array}$ \\
\hline \multicolumn{6}{|l|}{ Earnings } \\
\hline $\begin{array}{l}\text { Hause (1975) } \\
\text { Project Talent (white) }\end{array}$ & 1961 & $\begin{array}{l}19 \\
23\end{array}$ & $\begin{array}{l}\text { IQ, Test-Math } \\
\text { IQ,Test-Math }\end{array}$ & $\begin{array}{r}-3.7 \\
6.1\end{array}$ & $\begin{array}{l}- \\
-\end{array}$ \\
\hline
\end{tabular}

The table reports the percentage response of the wage rate or earnings to a one standard deviation improvement in a measure of academic achievement. For high school seniors a one standard deviation differential on an achievement test is about equal to 3.5 grade level equivalents or 110 points on the Verbal SAT. For GPA, one standard deviation is about .7 when $C^{\prime} s=2.0, B^{\prime} s=3.0$ and $\mathrm{A}^{\prime} \mathrm{s}=4.0$. 


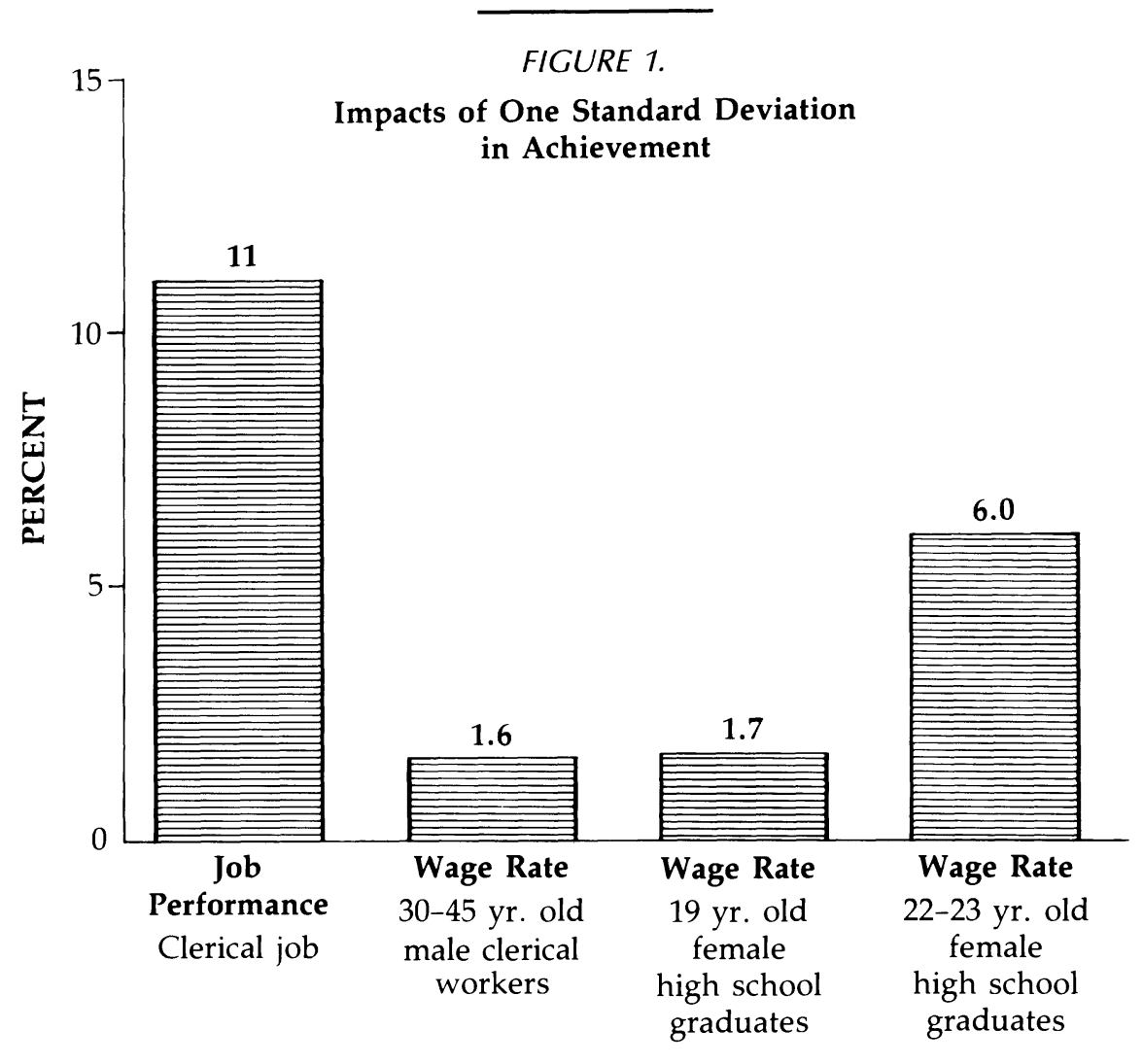

1982). Productivity clearly increases much more than wage rates. ${ }^{3} \mathrm{Ap}$ parently, it is a youth's employer, not the youth, who benefits the most when a student who isn't college-bound works hard in school and improves his or her academic achievements. The youth is more likely to find a job, but not one with an appreciably higher wage.

Reasons for the Discrepancy between Wage Rates and Productivity on the Job. Why doesn't competition between employers result in much higher wages for those who achieve more in high school? The lack of objective information available to employers on applicant accomplishments, skills, and productivity explains much. Tests are available for measuring competency in reading, writing, mathematics, science, and problem solving, but EEOC guidelines resulted in a drastic reduction in their use after 1971. A 1987 survey of a stratified random sample of small-and medium-sized employers who were members of the National Federation of Independent Business found that aptitude test scores had been obtained in only $3.15 \%$ of the hiring decisions studied.

Other potential sources of information on effort and achievement in high employees schools do respond, it takes a great deal of time. For Nationwide Insurance, the response almost invariably took more than 2 weeks. Given this time lag, if employers required transcripts prior to making hiring selections, a job offer could not be made until a month or so after an application had been received. Most jobs are filled much more rapidly than that.

The only information about school experiences requested by most employers is years of schooling, diplomas and certificates obtained, and area of specialization. Only $16 \%$ of the NFIB employers asked the applicants with 12 or fewer years of schooling to report their grade-point averages. The lack of application questions about school performance does not reflect an employer belief that school performance is a poor predicator of job performance. In policy capturing experiments (Hollenbeck \& Smith, 1984), grade-point average information had a major effect on the ratings employers assign to job applicants. The absence of questions about grades from most job applications probably reflects the low reliability of self-reported data, the difficulties of verifying it, and the fear of EEO challenges to such questions.

Hiring on the basis of recommendations by high school teachers is also uncommon. In the NFIB survey, when someone with 12 or fewer years of schooling was hired, the new hire had been referred or recommended by vocational teachers only in $5.5 \%$ of the cases and referred by someone else in the high school in only $3.1 \%$.

Clearly, hiring selections and starting wage rates often do not reflect the competencies and abilities students have developed in school. Instead, hiring decisions are based on observable characteristics (such as years of schooling and field of study) that serve as signals for the competencies the employer cannot observe directly. A study of how individual wage rates varied with initial job performance found that when people hired for the same or very similar jobs are compared, someone who is $20 \%$ more productive than average is typically paid only $1.6 \%$ more. After a year at a firm, better producers received only a $4 \%$ higher wage at nonunion firms with about 20 employees, and they had no wage advantage at unionized establishments with more than 100 employees or at nonunion establishments with more than 400 employees (Bishop, 1987a).

Employers structure their jobs this 
way because feasible measures of individual productivity are unreliable and unstable, because workers are reluctant to accept jobs in which the judgement of one supervisor can result in large wage declines, and because pay that is highly contingent on performance can weaken cooperation and generate incentives to sabotage others.

Despite their higher productivity, young workers who have achieved in high school do not receive appreciably higher wage rates after high school. The student who works hard must wait many years to reap rewards, and even then the magnitude of the wage and earnings effect-a 1 to $2 \%$ increase in earnings per grade level equivalent on achievement tests-is hardly much of an incentive. It is considerably smaller than the actual gain in productivity that results.

\section{The Zero-Sum Nature of Academic Competition in High School}

The second root cause of high school students' poor motivation is peer pressure against studying hard. The primary reason for peer pressure against studying is that pursuing academic success forces students into a zero-sum competition with their classmates. Their achievement is not being measured against an absolute, external standard. In contrast to scout merit badges, for example, where recognition is given for achieving a fixed standard of competence, the schools' measures of achievement assess performance relative to fellow students', through grades and class rank. When students try hard to excel, they set themselves apart, cause rivalries and may make things worse for friends. When we set up a zero sum competition among friends, we should not be surprised when they decide not to compete. All work groups have ways of sanctioning "rate busters." High school students call them "brain geeks," "grade grubbers," and "brown nosers."

Young people are not lazy. In their jobs after school and on the football field, they work very hard. In these environments they are part of a team where individual efforts are visible and appreciated by teammates. Competition and rivalry are not absent, but they are offset by shared goals, shared successes and external measures of achievement (i.e. satisfied customers or winning the game). On the sports field, there is no greater sin than giving up, even when the score is hopelessly one-sided. On the job, tasks not done by one worker will generally have to be completed by another. In too many high schools, when it comes to academics, a student's success is purely personal.

The second reason for peer norms against studying is that most students perceive the chance of receiving recognition for an academic achievement to be so slim they have given up trying. At most high school awards ceremonies, the academic recognition goes to only a few-those at the very top of the class. By 9th grade, most students are already so far behind the leaders, that they know they have no chance of being perceived as academically successful. Their reaction is often to denigrate the students who take learning seriously and to honor other forms of achievement-athletics, dating, holding their liquor, and being "cool"which offer them better chances of success.

The lack of external standards for judging academic achievement and the resulting zero sum nature of academic competition in the school also influences parents, school boards, and local school administrators. Parents can see that setting higher academic standards or hiring better teachers will not on average improve their child's rank in class or GPA. And raising standards at their daughter's high school will have only minor effects on how she does on the SAT, so why worry about standards? In any case, doing well on the SAT matters only for those who aspire to attend a selective college. Most students plan to attend open-entry public colleges, which admit all high school graduates from the state with the requisite courses. Scholarships are awarded on the basis of financial need, not academic merit.

The parents of children not planning to go to college have an even weaker incentive to demand high standards at the local high school. They believe that what counts in the labor market is getting the diploma, not learning algebra. They can see that learning more will be of only modest benefit to their child's future and that higher standards might put at risk what is really importantthe diploma.

Only when educational outcomes are aggregated, at the state or national levels, do the real costs of mediocre schools become apparent. The whole community loses because the work force is less efficient, and it becomes dif- ficult to attract new industry. Competitiveness deteriorates and the nation's standard of living declines. This is precisely why employers, governors, and state legislatures have been the energizing forces of school reform. State governments, however, are far removed from the classroom, and the instruments available to them for imposing reforms are limited. If students, parents, and school board officials perceive the rewards for learning to be minimal, state efforts to improve the quality of education will not succeed.

\section{Incentives to Learn in Other Nations}

The tendency not to reward effort and learning in high school appears to be a peculiarly American phenomenon. Marks in school are the major determinant of who gets the most preferred apprenticeships in Germany. In Canada, Australia, Japan, and Europe, the educational systems administer achievement exams that are closely tied to the curriculum. Performance on these exams is the primary determinant of admission to a university and to a field of study. Job applications, at all levels, require information about exam grades. Good grades on the toughest exams, those in physics, chemistry, and advanced mathematics, carry particular weight with employers and universities.

Parents in these countries know that a child's future depends critically on how much is learned in secondary school. In many countries the options for upper secondary schooling depend primarily on the child's performance in lower secondary school, not on where the parents can afford to live as in the U.S. National exams are the yardstick, so achievement tends to be measured relative to everyone else's in the nation and not just relative to the child's classmates. As a result, parents in most other Western nations demand more and get more from their local schools than we do. Take English-speaking Canada, for example. The $25 \%$ of Canadian 18-year-olds taking chemistry know just as much chemistry as the very select $1 \%$ of Americans who are taking their second high school chemistry course. The $28 \%$ taking biology know much more than the $6 \%$ of American 17- to 18-year-olds who are taking their second biology course (International Association for the Evaluation of Educational Achievement, 1988). In mathematics only $3 \%$ of American stu- 
dents achieve the standard reached by more than half of Japanese students.

\section{Thoughts on Solutions}

The key to motivation is recognizing and rewarding learning effort and achievement. Employers should start demanding high school transcripts and give academic achievement (particularly achievement in math and science) much greater weight when hiring. Business and industry should communicate this policy to schools, parents, and students. High school graduates should not be relegated to sales clerk jobs simply because of their age. Like their peers in Europe, Canada, and Japan, they should be allowed to compete for really attractive jobs on the basis of the knowledge and skills they have gained in high school.

Schools should reduce the disincentives to studying. Cooperative learning such as Student Teams-Achievement Divisions would encourage the peer group to reward learning effort by having students study in small heterogeneous groups and structuring competition between evenly matched teams, rather than unevenly matched individuals (Slavin, 1983). Criterion referenced competency profiles should be available for students, describing and certifying their academic, vocational, artistic, and extra-curricular accomplishments. Frequent awards ceremonies should recognize individual effort to attain learning goals, so that every student who works hard is recognized sometime in the school year. Those seeking work will be able to use their grades, as well as competency profiles and awards, as aids in securing employment.

Although the problems are less dramatic for the college-bound, parallel efforts should be made to increase incentives for them. College counselors and admission officers should deemphasize SATs, rank in class, and GPA and substitute criterion-referenced systems of assessment such as AP exams, in which the student is not engaged in zero sum competition with classmates. Although paper and pencil achievement tests tied to the state's curriculum should be part of this assessment, the measures of achievement available must be broadened to include such accomplishments as essay writing, conversing in a foreign language, conducting laboratory experiments, playing an instrument, repairing a car, and so forth.
Institutional arrangements of schools and the labor market have profound effects on the incentives available to students, teachers, parents, and school administrators. The passivity and inattention of students, the low morale of teachers, the defeat of so many school levies, and our low rankings on international measures of achievement are all logical outcomes of institutional arrangements that weaken student's incentives to study and their parents' incentives to demand high quality education for them. Only with an effective system of rewards within the schools and the labor market can we hope to overcome the pervasive apathy in American high schools and achieve excellence.

${ }^{1}$ The number of useable respondents was 2014

${ }^{2}$ These tests measure the competencies that are the prime objectives of schooling. School attendance has been shown to improve performance on these tests (Lorge, 1945). Between World War I and World War II, the average IQ test scores of literate white army draftees increased by 11 points.

${ }^{3}$ Studies that measure output for different workers in the same job at the same firm, using physical output as a criterion, have found that the standard deviation of output varies with job complexity and averages about .164 in routine clerical jobs and .278 in clerical jobs with decision making responsibilities (Hunter, Schmidt, \& Judiesch, 1988). Because there are fixed costs to employing an individual (facilities, equipment, light, heat, and overhead functions such as hiring and payrolling), the coefficient of variation of marginal products of individuals is assumed to be 1.5 times the coefficient of variation of productivity. Because about $2 / 3$ rds of clerical jobs can be classified as routine, the coefficient of variation of marginal productivity for clerical jobs is $30 \%$ [ $1.5 \times(.33$ x.278+.67x.164)]. A .5 validity for general mental ability then implies that an academic achievement differential between two individuals of one standard deviation (in a distribution of high school graduates) is associated with a productivity differential in the job of about $11 \%(.5 \times .74 \times 30 \%)$. The ratio of the high school graduate test score standard deviation to the population standard deviation is assumed to be .74 . This issue is more thoroughly discussed in Bishop (1987b).

Bishop, J. (1987a, October). The recognition and reward of employee performance. Journal of Labor Economics, 5(4), S36-S56.

Bishop, J. (1987b). Information externalities and the social payoff to academic achievement. Ithaca, NY: Cornell University, Center for Advanced Human Resource Studies.

Daymont, T. N., \& Rumberger, R. W. (1982). Job training in the schools. In R. Taylor, $\mathrm{H}$. Rosen, \& F. Pratzner (Eds.), Job training for youth. Columbus, $\mathrm{OH}$ : The Ohio State
University, The National Center for Research in Vocational Education.

Fischer, C. W., Filby, N. N., Marliave, R. S., Cahen, L. S., Dishaw, N. N., Moore, J. E., \& Berliner, D. C. (1978). Teaching behaviors, academic learning time and student achievement: Final report of Phase III-B. (Technical Report V-I). San Francisco, CA: Far West Laboratories.

Frederick, W. C. (1977, January). The use of classroom time in high schools above or below the median reading score. Urban Education, 11(4) 459-464.

Frederick, W., Walberg, H., \& Rasher, S. (1979, November-December). Time, teacher comments, and achievement in urban high schools, Journal of Educational Research, 73(2), 63-65.

Gardner, J. A. (1982). Influence of high school curriculum on determinants of labor market experience. Columbus, $\mathrm{OH}$ : The Ohio State University, The National Center for Research in Vocational Education.

Ghiselli, E. E. (1973). The validity of aptitude tests in personnel selection. Personnel Psychology, 26, 461-477.

Goodlad, J. (1983). A place called school. New York: McGraw-Hill.

Hause, J. C. (1975). Ability and schooling as determinants of lifetime earnings, or if you're so smart, why aren't you rich. In F. T. Juster (Ed.), Education, Income, and Human Behavior. New York: McGraw-Hill.

Hollenbeck, K., \& Smith, B. (1984). The influence of applicants' education and skills on employability assessments by employers. Columbus, $\mathrm{OH}$ : The Ohio State University, The National Center for Research in Vocational Education.

Hotchkiss, L., Bishop, J. H., \& Gardner, J. (1982). Effects of individual and school characteristics on part-time work of high school seniors. Columbus, $\mathrm{OH}$ : The Ohio State University, The National Center for Research in Vocational Education.

Hunter, J. E., Schmidt, F. L., \& Judiesch, M. K. (1988, June). Individual differences in output as a function of job complexity. Iowa City, IA: University of Iowa, Department of Industrial Relations and Human Resources.

International Association for the Evaluation of Educational Achievement. (1988). Science achievement in seventeen nations. New York: Pergammon Press.

Kang, S., \& Bishop, J. (1984). The impact of curriculum on the non-college bound youth's labor market outcomes. In L. Hotchkiss, J. Bishop, \& S. Kang (Eds.), High school preparation for employment (pp. 95-135). Columbus, $\mathrm{OH}$ : The Ohio State University, The National Center for Research in Vocational Education.

Klein, M. F., Tyle, K. A., \& Wright, J. E. (1979, December). A study of schooling curriculum. Phi Delta Kappan, 61(4) 244-248.

Krista (1987). Unpublished paper, Cornell University, Ithaca, NY.

Longitudinal Survey of American Youth. (1988). Data file user's manual. Dekalb, IL: Public Opinion Laboratory.

Lorge, I. (1945). Schooling makes a difference. Teachers College Record, 46, 483-492.

Meyer, R. (1982). Job training in the schools. In R. Taylor, H. Rosen, \& F. Pratzner

Continued on page 42 
Lave, J. (1988b). Cognition in practice. Boston, MA: Cambridge.

Lave, J. (1988c). Word problems: A microcosm of theories of learning. Paper presented at AERA annual conference, New Orleans, LA.

Lave, J. (in preparation). Tailored learning: Education and everyday practice among craftsmen in West Africa.

Lave, J., \& Wenger, E. (in preparation). Situated learning: Legitimate peripheral participation.

McCloskey, M., Caramazza, A., \& Green, B. (1980). Curvilinear motion in the absence of external forces: Naive beliefs about the motion of objects. Science, 210, 1139-1141.

Miller, G. A., \& Gildea, P. M. (1987). How children learn words. Scientific American,
257, (3), 94-99.

Nunberg, G. (1978). The pragmatics of reference. Bloomington, IN: Indiana University Linguistics Club.

Orr, J. (1987). Talking about machines. (SSL Report). Palo Alto, CA: Xerox Palo Alto Research Center.

Palincsar, A. S. (1986). Metacognitive strategy instruction. Exceptional Children, 53, 118-124.

Palincsar, A. S. \& Brown, A. L. (1984) Reciprocal teaching of comprehensionfostering and monitoring activities. Cognition and Instruction, 1, 117-175

Pea, R. D. (1988). Distributed intelligence in learning and reasoning processes. Paper presented at the meeting of the Cognitive Science Society, Montreal.

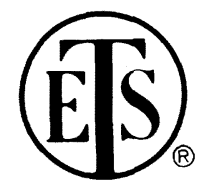

\section{Educational Testing Service 1989-90 Fellowship Programs William H. Angoff, Director}

Educational Testing Service invites applications for the ETS Postdoctoral Fellowship Program and the National Assessment of Educational Progress (NAEP) Visiting Scholar Program.

\section{Programs}

\section{ETS Postdoctoral Fellowship Program}

Up to four participants will conduct research for 1 year (September 1, 1989, through July 31,1990 ) at ETS in Princeton, NJ, in association with ETS senior staff in one of the following areas: psychometrics, cognitive psychology, educational psychology, statistics, higher education, technology, occupational/vocational testing, minority issues, testing issues, or policy studies. Stipend: $\$ 24,000$. Some relocation expenses will be included, as will a small allowance for an accompanying family.

Goals of the Program: To provide research opportunities for recent awardees of the doctorate and to increase the number of women and minority professionals working in the areas specified above.

Who Should Apply: The program is open to any individual who holds a doctorate in a relevant discipline and provides evidence of prior research.

\section{National Assessment of Educational Progress (NAEP) Visiting Scholar} Program

One or two participants, using the NAEP data base, will conduct their own studies (normally from September 1, 1989, through July 31, 1990) at ETS in Princeton, NJ, with access to senior NAEP and ETS research staff. Studies should pertain to educational policy or measurement issues associated with black, Hispanic, or other minority students. Stipend: set in relation to compensation at home institution. Some reloca. tion expenses will be included, as will a small allowance for an accompanying family. Goals of the Program: To provide research opportunities for recent awardees of the doctorate and to increase the number of women and minority professionals work. ing in the areas specified.

Who Should Apply: The program is open to any individual who holds a doctorate in a relevant discipline and provides evidence of prior research.

How to Apply (There is no special application form.)

Applicants should submit:

- A resume of educational and job history, honors, awards, etc.

- A detailed description of research interests and experience, plus a description of the nature of the research the applicant would be interested in pursuing during the fellowship year (letter of about three pages).

- Names, addresses, and telephone numbers of three individuals who are willing to provide recommendations for the candidate.

- Transcripts-undergraduate and graduate.

An applicant should specify the program for which he or she is applying.

Applications for 1989-90 must be received by ETS on or before February 1, 1989. All applicants will be notified by April 30, 1989.

Contact: Direct required materials and inquiries to: Margaret B. Lamb, ETS, Mail Stop 30-B, Princeton, NJ 08541-0001; telephone (609) 734-1124.
Perkins, D. N. (1986). Knowledge as design. Hillsdale, NJ: Erlbaum.

Perry, J. (1979). The problem of the essential indexical. Nous, 13, 3-21.

Resnick, L. (1988). Learning in school and out. Educational Researcher, 16(9), 13-20.

Rogoff, B., \& Lave, J. (Eds.). (1984). Everyday cognition: Its development in social context. Cambridge, MA: Harvard University Press.

Rubin, A. (1980). A theoretical taxonomy of the differences between oral and written language. In R. J. Spiro, B. C. Bruce, \& W. F. Brewer (Eds.), Theoretical issues in reading comprehension (pp. 411-438). Hillsdale, NJ: Erlbaum.

Scardamalia, M., Bereiter, C., \& Steinbach, R (1984). Teachability of reflective processes in written composition. Cognitive Science, 8, 173-190.

Schoenfeld, A. H. (1985). Mathematical problem solving. Orlando, FL: Academic Press.

Schoenfeld, A. H. (in press). On mathematics as sense-making: An informal attack on the unfortunate divorce of formal and informal mathematics. In D. N. Perkins, J. Segal, \& J. Voss (Eds.), Informal reasoning and education. Hillsdale, NJ: Erlbaum.

Schoenfeld, A. H. (in preparation). Ideas in the air. (IRL report 88-0011). Palo Alto, CA: Institute for Research on Learning.

Scribner, S. (1984). Studying working intelligence. In B. Rogoff \& J. Lave (Eds.), Everyday cognition: Its development in social context (pp. 9-40). Cambridge, MA: Harvard University Press.

Shanker, A. (1988). Exploring the missing connection. New York Times, E7.

Suchman, L. (1987). Plans and situated actions. New York: Cambridge University Press.

White, B. (1983). Sources of difficulty in understanding Newtonian dynamics. Cognitive Science, 7, 41-65.

Whitehead, A. N. (1929). The aims of education. Cambridge: Cambridge University Press.

Continued from page 10

(Eds.), Job training for youth. Columbus, $\mathrm{OH}$ : The Ohio State University, The National Center for Research in Vocational Education.

National Federation of Independent Business. (1987). [Survey of a stratified random sample.] Unpublished raw data.

A. C. Nielsen Company. (1987). Unpublished raw data.

Organization of Economic Cooperation and Development. (1986). Living conditions in OECD countries: A compendium of social indicators. Social Policy Studies No. 3. Paris, France: Author.

Sizer, T. R. (1984). Horace's compromise: The dilemma of the American high school. Boston, MA: Houghton Mifflin.

Slavin, R. (1983). When does cooperative learning increase student achievement? Psychological Bulletin, 99, 429-445.

Stevenson, H., Lee, S., \& Stigler, J. W. (1986, February). Mathematics achievement of Chinese, Japanese \& American children Science, 231, 693-699.

Taubman, P., \& Wales, T. (1975). Education as an investment and a screening device. In F. T. Juster (Ed.), Education, income, and human behavior. New York: McGraw-Hill. 